Article

\title{
Facile Functionalization of Electrospun Poly(ethylene-co-vinyl alcohol) Nanofibers via the Benzoxaborole-Diol Interaction
}

\author{
Yohei Kotsuchibashi ${ }^{1, *}$ and Mitsuhiro Ebara ${ }^{2,3}$ \\ 1 International Center for Young Scientists (ICYS) and International Center for Materials \\ Nanoarchitectonics (WPI-MANA), National Institute for Materials Science (NIMS), 1-1 Namiki, Tsukuba, \\ Ibaraki 305-0044, Japan \\ 2 Biomaterials Unit, WPI-MANA, NIMS, 1-1 Namiki, Tsukuba, Ibaraki 305-0044, Japan; \\ EBARA.Mitsuhiro@nims.go.jp \\ 3 Graduate School of Industrial Science and Technology, Tokyo University of Science, 6-3-1 Niijuku, \\ Katsushika, Tokyo 125-8585, Japan \\ * Correspondence: KOTSUCHIBASHI.Yohei@nims.go.jp; Tel.: +81-29-851-3354 (ext. 8918); \\ Fax: +81-29-860-4762
}

Academic Editor: Hatsuo Ishida

Received: 1 December 2015; Accepted: 29 January 2016; Published: 5 February 2016

\begin{abstract}
A facile functionalization method of poly(ethylene-co-vinyl alcohol) (EVOH) nanofiber meshes was demonstrated by utilizing the benzoxaborole-diol interaction between EVOH and benzoxaborole-based copolymers (BOP). EVOH and BOP were firstly mixed to prepare the quasi-gel-state solution with enough viscosity for electro-spinning. The fiber morphology was controlled via changing the mixing ratio of $\mathrm{EVOH}$ and $\mathrm{BOP}$. The prepared $\mathrm{EVOH} / \mathrm{BOP}$ nanofiber mesh showed good stability in aqueous solution. Over $97 \%$ of the nanofibers remained after the immersion test for $24 \mathrm{~h}$ in acid or alkali aqueous solutions without changing their morphology. Temperature and $\mathrm{pH}$-responsive moieties were copolymerized with $\mathrm{BOP}$, and cationic dye was easily immobilized into the nanofiber mesh via an electrostatic interaction. Therefore, the proposed functionalization technique is possible to perform on multi-functionalized molecule-incorporated nanofibers that enable the fibers to show the environmental stimuli-responsive property for the further applications of the EVOH materials.
\end{abstract}

Keywords: benzoxaborole; boroxole; poly(ethylene-co-vinyl alcohol); nanofiber; electrospinning; gel; smart polymer; stimuli response; $\mathrm{pH}$ response

\section{Introduction}

Poly(ethylene-co-vinyl alcohol) (EVOH) has been one of the best known flexible thermoplastic materials and used in a wide range of fields, such as food packaging, funnel tanks, and medical applications for the high gas-barrier and biocompatibility [1-3]. The fabrication of EVOH materials has been customized dependent on the choice of applications, such as films [4], (nano)particles [5], porous materials [6] and (nano)fibers [7,8].

Moreover, these EVOH materials have been modified with molecules/polymers to enhance their functionalities. The modification, however, is limited due to the multi-steps of the reaction processes. Therefore, a simple modification system for $\mathrm{EVOH}$ materials has been focused on recently. Zhou et al. prepared a phosphorylcholine-modified EVOH in two reaction steps to prevent nonspecific protein adsorption [9]. Zhu et al. modified chelating groups on EVOH nanofibers via a three-step treatment, the modified nanofibers were used for a selective protein separation system [10]. Plasma treatment achieves a one-step modification for $\mathrm{EVOH}$ materials. By the treatment, however, the EVOH 
composition was changed via the newly-generated groups, such as carboxylic acid. The conversion also leads to a change of the physicochemical properties of the original EVOH [11]. As other one-step modifications for EVOH materials, there is a blending method with hydrophobic polymers via the hydrophobic-hydrophobic interaction [12]. The mechanical properties of EVOH nanofibers were strengthened by mixing with polymers, such as polypropylene (PP) [13], poly(lactic acid) (PLA) [14], cellulose [15] and Nylon 6/12 [16]. However, it is difficult to obtain stable EVOH blend materials with a hydrophilic polymer in aqueous solution because of their weak interactions. Stable EVOH and hydrophilic polymer blends in aqueous solution were reported using multi-step treatments, such as a polymerization of hydrophilic polymers from the EVOH surface $[17,18]$ and a cross-linking method after the blend process [19]. Moreover, a copolymerization of ethylene, vinyl acetate (precursor of vinyl alcohol) and hydrophilic monomers is expected to obtain a modified EVOH with hydrophilic units. However, typical (meth)acrylate and (meth)acrylamide monomers have different reaction ratios with ethylene and vinyl acetate due to their structure, which leads to low yields and a gradient composition [20]. Therefore, it remains a challenge to propose a simple EVOH function system. To achieve this system, we focused on a dynamic covalent chemistry [21,22].

Recently, we have reported a hydrogel gel system using reversible covalent bonding between benzoxaborole-based temperature-responsive copolymers and glyco-based copolymers [23,24]. The benzoxaborole unit can reversibly combine with the cis-diol in the glyco-based copolymers. The mixed hydrogels displayed temperature-responsive, $\mathrm{pH}$-responsive and glucose-responsive properties. Moreover, a photo-acid generator of 2-nitrobenzaldehyde (2-NBA) that possesses a proton-release by UV irradiation [25] was encapsulated into the hydrogel. The UV irradiation caused the disintegration of the hydrogel structure in the exposed region, resulting in the local $\mathrm{pH}$ decrease. The benzoxaborole units have also been applied in biomedical fields, such as the selective binding with the Thomsen-Friedenreich (TF)-antigen disaccharide, delivery of a protein toxin in the cytosol, neutralization of human immunodeficiency virus (HIV) and antitrypanosomal agent [26-30].

In this study, EVOH was mixed with the water-soluble benzoxaborole-based copolymers (BOPs) in organic solvent and was found to show a gelation via a benzoxaborole-diol interaction. The functionalized EVOH nanofiber meshes with BOP were prepared by electro-spinning using the mixed viscous solution (Figure 1). The nanofiber meshes had a stable cross-linked structure in aqueous solution due to the reversible covalent bonding. Using this simple method, the EVOH nanofibers were successfully functionalized with stimuli-responsive copolymers. To the best of our knowledge, this is the first report on functionalized EVOH materials with BOPs. The stability and functionality of the $\mathrm{EVOH} / \mathrm{BOP}$ nanofiber meshes were investigated in various solution conditions.

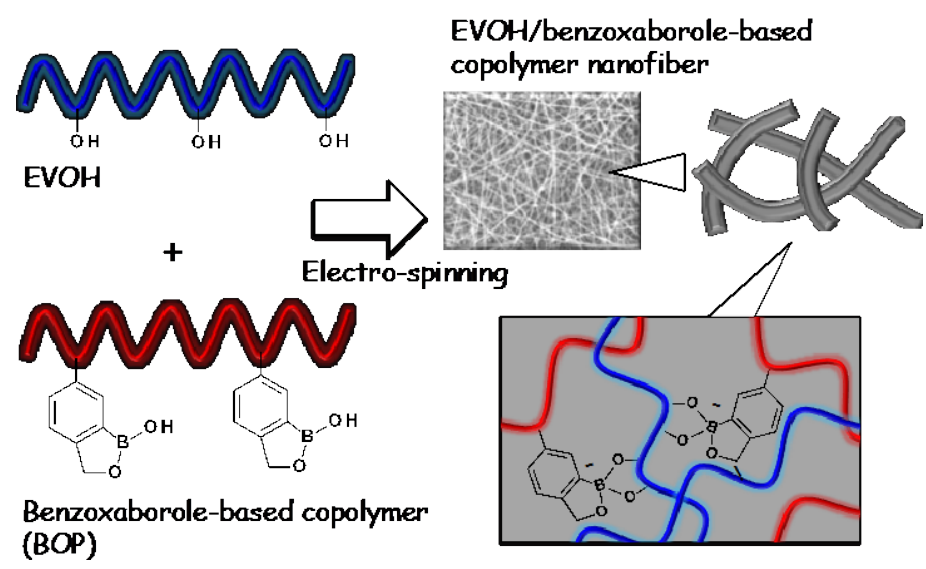

Figure 1. Schematic representation of modified EVOH nanofiber with benzoxaborole-based copolymers (BOPs). 


\section{Experimental Section}

\subsection{Material}

Five-methacrylamido-1,2-benzoxaborole (MAAmBO) was synthesized and purified according to the protocol given [23,24]. One-pyrenemethyl methacrylate (PyMA) was purified by recrystallization from ethanol. Two-(2-methoxyethoxy)ethyl methacrylate $\left(\mathrm{MEO}_{2} \mathrm{MA}\right)$, oligo(ethylene glycol) methacrylate (OEGMA, $M_{\mathrm{n}}=475 \mathrm{~g} / \mathrm{mol}$ ) and acrylic acid (Ac) were purchased from Sigma-Aldrich (St. Louis, MO, USA) and purified by passing through a basic alumina column. EVOH (EVAL E105A, $44 \mathrm{~mol} \%$ ethylene) was kindly supplied from KURARAY (Okayama, Japan). All other chemicals and solvents were used as received. Distilled water used in this study was purified with a Millipore Milli-Q system.

\subsection{Preparation of Benzoxaborole-Based Copolymers}

Reversible addition-fragmentation chain transfer (RAFT) polymerization was employed to synthesize copolymers with a narrow molecular weight distribution. The polymerization methods of BOPs are described in the Supplementary Materials. Briefly, $\mathrm{MEO}_{2} \mathrm{MA}(540 \mathrm{mg}, 2.87 \mathrm{mmol}$ ), OEGMA (908 mg, $1.91 \mathrm{mmol})$, MAAmBO (116 mg, $0.53 \mathrm{mmol})$, 4-cyanopentanoic acid dithiobenzoate (CTP) (7.42 mg, $\left.2.66 \times 10^{-2} \mathrm{mmol}\right)$ and 4,4'-azobis-4-cyanovaleric acid (ACVA) $\left(2.98 \mathrm{mg}, 1.06 \times 10^{-2} \mathrm{mmol}\right)$ $\left(\left[\mathrm{MEO}_{2} \mathrm{MA}_{0} /[\mathrm{OEGMA}]_{0} /[\mathrm{MAAmBO}]_{0} /[\mathrm{CTP}]_{0} /[\mathrm{ACVA}]_{0}=108 / 72 / 20 / 1 / 0.4\right)\right.$ were dissolved in $4 \mathrm{~mL}$ of methanol. After degassing with nitrogen gas for $30 \mathrm{~min}$, the mixture was allowed to polymerize for $24 \mathrm{~h}$ at $60^{\circ} \mathrm{C}$. The resulting $\mathrm{P}\left(\mathrm{MEO}_{2} \mathrm{MA}-\mathrm{co}\right.$-OEGMA-co-MAAmBO $)$ was purified by dialysis against ethanol and acetone and was dried under reduced pressure. The preparation conditions of other BOPs are shown in the Supplementary Materials.

\subsection{Preparation of $E V O H / B O P$ Nanofiber Meshes}

BOPs were dissolved in 1,1,1,3,3,3-hexafluoroisopropanol (HFIP) at room temperature. Electro-spinning was performed using a Nanon-01A (MECC, Fukuoka, Japan). Spinning parameters were kept constant at a $25-\mathrm{kV}$ applied voltage, a $1.0-\mathrm{mL} / \mathrm{h}$ solution flow rate, a $15-\mathrm{cm}$ working distance and a 25-gauge pointed needle [8]. The fibers were electrospun onto a sheet of aluminum foil on a stationary plate collector. The fibers were directly extracted from the foil.

\subsection{Stability Tests}

Nanofiber meshes of EVOH and BOPs (P(MEO $\left.{ }_{2} \mathrm{MA}-c o-M A A m B O-c o-P y M A\right)$ or $\mathrm{P}\left(\mathrm{MEO}_{2} \mathrm{MA}-c o-\mathrm{PyMA}\right)$ ) were prepared for stability tests in various solution conditions $(\mathrm{pH}$ $2 / 37{ }^{\circ} \mathrm{C}, \mathrm{pH} 2 / 4{ }^{\circ} \mathrm{C}, \mathrm{pH} 12 / 37{ }^{\circ} \mathrm{C}$ and $\mathrm{pH} 12 / 4{ }^{\circ} \mathrm{C}$ ). The PyMA units were used to detect the amount of released BOPs from the nanofibers. The BOP and EVOH were dissolved in HFIP at 2 and $7 \mathrm{wt} \%$ concentrations, respectively. Each $2.5-\mathrm{mL}$ polymer solution was mixed and was kept at least $1 \mathrm{~h}$ to reach the equilibrium before electro-spinning. Nanofiber meshes were cut $(2.70-3.79 \mathrm{mg})$ as a square sample and were added to $\mathrm{pH} 2(0.01 \mathrm{~N} \mathrm{HCl})$ or $\mathrm{pH} 12(0.01 \mathrm{~N} \mathrm{NaCl})$ solution to be the same concentration ( $0.3 \mathrm{wt} \%$, e.g., $3 \mathrm{mg}$ of fiber sample was added to $1 \mathrm{~mL}$ solution). After $24 \mathrm{~h}$, all nanofiber samples were washed with Milli-Q and were dried under atmospheric pressure. The morphology and weight of the nanofiber meshes were measured. Each nanofiber sample was measured at 3 different places $(N=3)$.

\subsection{Characterizations}

${ }^{1} \mathrm{H}$ NMR spectra of copolymers were taken with a JNM-GSX300 spectrometer operating at $300 \mathrm{MHz}$ (JEOL, Tokyo, Japan) to confirm successful synthesis and to determine the chemical composition of the synthesized copolymers. Molecular weight and polydispersity of the synthesized copolymers were determined by gel permeation chromatography (GPC) at $40{ }^{\circ} \mathrm{C}$ (DMF, including 
$10 \mathrm{mM} \mathrm{LiBr}, 1 \mathrm{~mL} / \mathrm{min}$ ) with a TOSOH TSK-GEL a-2500 and a-4000 and (Tosoh, Tokyo, Japan) connected to an RI-2031 refractive index detector (JASCO International Co. Ltd., Tokyo, Japan). Transmittance of a copolymer solution at $500 \mathrm{~nm}$ was continuously recorded at a heating rate of $1.0^{\circ} \mathrm{C} / \mathrm{min}$ by a UV-Vis spectrometer V-550 (JASCO International Co. Ltd., Tokyo, Japan) to measure the lower critical solution temperature (LCST). Synthesized copolymers were dissolved in aqueous solution at the given concentration. LCSTs of copolymers were determined at $50 \%$ transmittance. Fluorescence spectra were recorded using a fluorescence spectrometer F-2500 (Hitachi High-Technologies Corporation, Tokyo, Japan). The morphologies of nanofiber meshes were observed using a NEO-Scope JCM-5000 SEM (JEOL, Tokyo, Japan).

\section{Results and Discussion}

\subsection{Preparation of Benzoxaborole-Based Copolymers}

The BOPs were polymerized by the reversible addition-fragmentation chain transfer (RAFT) polymerization. Boronic acids and their esters can reversibility interact with the cis-diol group. The interaction between phenylboronic acid (PBA) and glucose has been utilized as a trigger for an insulin release system that was incorporated into newly-designed polymeric materials [31-33]. Recently, Hall and co-workers reported that the benzoxaborole molecule showed a higher affinity than boronic acid toward saccharides in phosphate-buffered saline (PBS) [34]. The high affinity comes from the relatively low $\mathrm{pKa}$ of the benzoxaborole $\left(\mathrm{pK}_{\mathrm{a}} 7-8\right)$ as compared to that of boronic acid ( $\left.\mathrm{pK}_{\mathrm{a}} 8-9\right)$ [35,36]. In this study, benzoxaborole-based monomers were copolymerized with functional monomers for the functionalization of EVOH nanofiber meshes (Figure 2). The compositions of the BOPs are summarized in Table 1. The copolymers, $\mathrm{P}\left(\mathrm{MEO}_{2} \mathrm{MA}-\mathrm{co}-\mathrm{MAAmBO}\right)$, $\mathrm{P}\left(\mathrm{MEO}_{2} \mathrm{MA}-c o-\mathrm{OEGMA}-c o-\mathrm{MAAmBO}\right)$ and $\mathrm{P}\left(\mathrm{MEO}_{2} \mathrm{MA}-c o-\mathrm{MAAmBO}-c o-\mathrm{Ac}\right)$ were prepared. The monomers of $\mathrm{MEO}_{2} \mathrm{MA}$ and OEGMA were selected in order to control the temperature-responsive properties, i.e., lower critical solution temperature (LCST). The LCSTs of $\mathrm{P}\left(\mathrm{MEO}_{2} \mathrm{MA}\right)$ and $\mathrm{P}(\mathrm{OEGMA})$ homopolymers were 28 and $90^{\circ} \mathrm{C}$, respectively [37]. The Ac monomer with carboxylic acid functionality was used to donate the $\mathrm{pH}$-responsive property to the BOPs. Moreover, the anionic charge can interact with cationic molecules via electrostatic interactions. The compositions $(\mathrm{mol} \%)$ of the BOPs were measured using ${ }^{1} \mathrm{H}$ NMR and are shown at the right side of monomer unit ( $\left(\mathrm{MEO}_{2} \mathrm{MA}_{91.0}-c o-\mathrm{MAAmBO}_{9.0}\right), \mathrm{P}\left(\mathrm{MEO}_{2} \mathrm{MA}_{56.5}-c o-\mathrm{OEGMA}_{38.2}\right.$-co-MAAmBO $\left.\mathrm{MA}_{5.3}\right)$ and $\mathrm{P}\left(\mathrm{MEO}_{2} \mathrm{MA}_{86.7}-\mathrm{co}-\mathrm{MAAmBO}_{4.8}-\mathrm{co}-\mathrm{Ac} \mathrm{c}_{8.5}\right)$. Molecular weight $\left(M_{\mathrm{n}}\right)$ and $M_{\mathrm{w}} / M_{\mathrm{n}}$ of the BOPs were calculated from GPC measurement. However, broad GPC peaks were observed in all BOPs $\left(40{ }^{\circ} \mathrm{C}\right.$, DMF including $\left.10 \mathrm{mM} \mathrm{LiBr}, 1 \mathrm{~mL} / \mathrm{min}\right)$. This might be an adsorption between MAAmBO units and the filler of the GPC column. Therefore, the benzoxaborole units were protected with 1,4-butanediol to prevent the adsorption [38], and the molecular weights were measured using the same GPC conditions. The molecular weights were smaller than those of

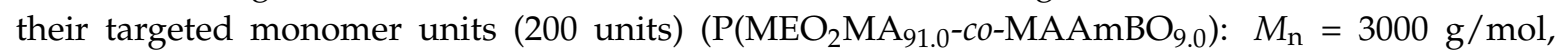
$M_{\mathrm{W}} / M_{\mathrm{n}}=1.26 ; \mathrm{P}\left(\mathrm{MEO}_{2} \mathrm{MA}_{56.5}\right.$-co-OEGMA 38.2 -co-MAAmBO $\left.{ }_{5.3}\right): M_{\mathrm{n}}=6000 \mathrm{~g} / \mathrm{mol}, M_{\mathrm{w}} / M_{\mathrm{n}}=1.80$; and $\left.\mathrm{P}\left(\mathrm{MEO}_{2} \mathrm{MA}_{86.7}-\mathrm{co}-\mathrm{MAAmBO}_{4.8}-\mathrm{co}-\mathrm{Ac}_{8.5}\right): M_{\mathrm{n}}=2300 \mathrm{~g} / \mathrm{mol}, M_{\mathrm{w}} / M_{\mathrm{n}}=1.32\right)$. The estimated low molecular weights might come from the unprotected benzoxaborole units and the solubility change that occurred due to the protecting groups. The stimuli-responsive properties of BOPs were measured using the transmittance change as a function of temperature (Figures S1 and S2). The LCST of the $\mathrm{P}\left(\mathrm{MEO}_{2} \mathrm{MA}_{91.0}-\mathrm{co}-\mathrm{MAAmBO}_{9.0}\right)$ was around $18.3^{\circ} \mathrm{C}$ at $\mathrm{pH} 2\left(0.01 \mathrm{~N} \mathrm{HCl}_{\mathrm{aq}}\right)$ (Figure S1A). The hydrophobic MAAmBO units led to a decrease in the LCST. On the other hand, at $\mathrm{pH} 12\left(0.01 \mathrm{~N} \mathrm{NaOH}_{\mathrm{aq}}\right)$, the transmittance change of $\mathrm{P}\left(\mathrm{MEO}_{2} \mathrm{MA}_{91.0}-\mathrm{co}-\mathrm{MAAmBO}_{9.0}\right)$ disappeared due to the anionic charged MAAmBO units, resulting in the electrostatic repulsion. The LCST

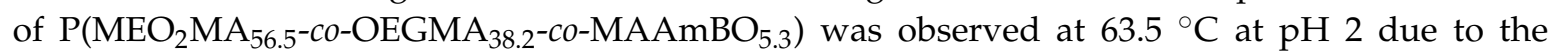
hydrophilic OEGMA units, and no transmittance change was observed at $\mathrm{pH} 12$ (Figure S1B). These results suggested that the LCST of the BOPs could be easily controlled by the copolymerized 
monomer compositions. $\mathrm{P}\left(\mathrm{MEO}_{2} \mathrm{MA}_{86.7}-\mathrm{co}-\mathrm{MAAmBO}_{4.8^{-c o}-\mathrm{Ac}} \mathrm{C}_{8.5}\right)$ had the carboxylic acid groups as the $\mathrm{pH}$-responsive units. At $\mathrm{pH} 2$, the LCST was $17.6^{\circ} \mathrm{C}$. On the other hand, at $\mathrm{pH} 12$, no transmittance change was observed due to the electrostatic repulsion of both MAAmBO and Ac units (Figure S1C).

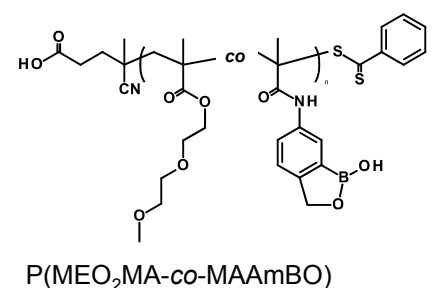

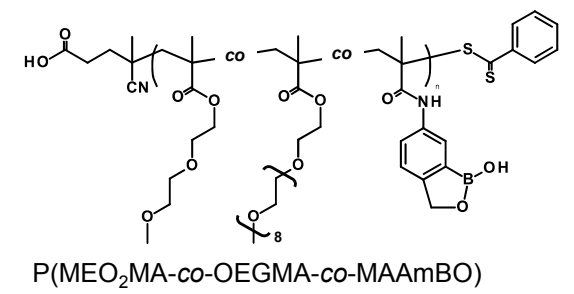

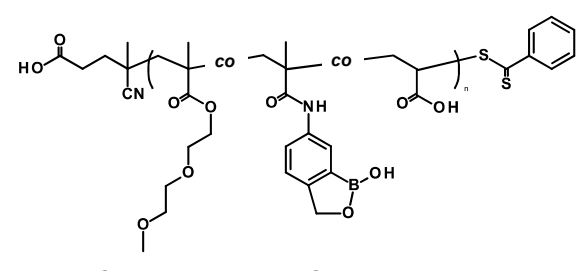

$$
\text { † } \overbrace{\mathrm{OH}} \mathrm{t}^{\circ}
$$

$\mathrm{P}\left(\mathrm{MEO}_{2} \mathrm{MA}-\mathrm{co}-\mathrm{MAAmBO}-\mathrm{co}-\mathrm{Ac}\right)$

Poly(ethylene-co-vinyl alcohol) (EVOH)

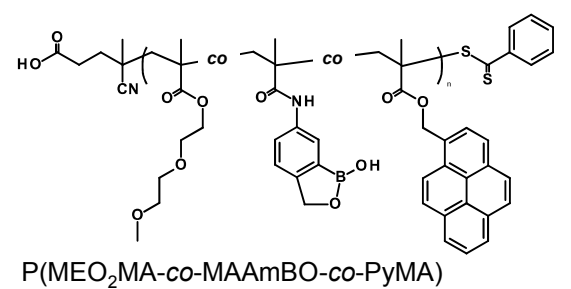

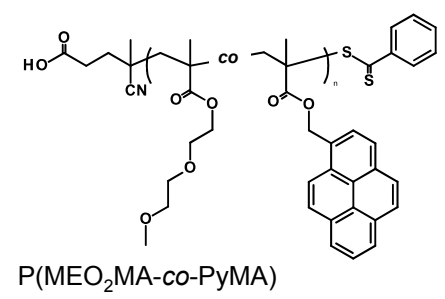

Figure 2. Chemical structure of BOPs and EVOH. $\mathrm{MEO}_{2} \mathrm{MA}$, two-(2-methoxyethoxy)ethyl methacrylate; MAAmBO, five-methacrylamido-1,2-benzoxaborole; OEGMA, oligo(ethylene glycol) methacrylate; Ac, acrylic acid; PyMA, one-pyrenemethyl methacrylate.

Table 1. Characterization of BOPs. LCST, lower critical solution temperature.

\begin{tabular}{|c|c|c|c|c|c|c|c|c|c|}
\hline \multirow{2}{*}{ Copolymer } & \multicolumn{5}{|c|}{ In Copolymer $(\mathrm{mol} \%)^{a}$} & \multirow[t]{2}{*}{$M_{\mathrm{n}}{ }^{\mathrm{b}}(\mathrm{g} / \mathrm{mol})$} & \multirow[t]{2}{*}{$M_{\mathrm{w}} / M_{\mathrm{n}}{ }^{\mathrm{b}}(-)$} & \multicolumn{2}{|c|}{$\operatorname{LCST}\left({ }^{\circ} \mathrm{C}\right)^{\mathrm{c}}$} \\
\hline & $\mathrm{MEO}_{2} \mathrm{MA}$ & MAAmBO & OEGMA & Ac & PyMA & & & $\mathrm{pH}^{\mathrm{d}}$ & $\mathrm{pH} 12{ }^{\mathrm{e}}$ \\
\hline $\begin{array}{l}\mathrm{P}\left(\mathrm{MEO}_{2} \mathrm{MA}_{91.0^{-}}\right. \\
\left.\text {co-MAAmBO } \mathrm{MAO}_{9.0}\right)\end{array}$ & 91.0 & 9.0 & - & - & - & 3000 & 1.26 & 18.3 & no $\operatorname{LCST}^{\mathrm{f}}$ \\
\hline $\begin{array}{c}\mathrm{P}_{\left(\mathrm{MEO}_{2} \mathrm{MA}_{56.5^{-}}\right.} \text {co-OEGMA } 38.2^{-} \\
\left.c o-\mathrm{MAAmBO}_{5.3}\right)\end{array}$ & 56.5 & 5.3 & 38.2 & - & - & 6000 & 1.80 & 63.5 & no $\operatorname{LCST}^{\mathrm{f}}$ \\
\hline $\begin{array}{c}\mathrm{P}\left(\mathrm{MEO}_{2} \mathrm{MA}_{86.7^{-}}\right. \\
\text {co- } \mathrm{MAAmBO}_{4.8^{-}} \\
{\left.\text {co- } \mathrm{Ac}_{8.5}\right)}\end{array}$ & 86.7 & 4.8 & - & 8.5 & - & 2300 & 1.32 & 17.6 & no LCST $\mathrm{g}$ \\
\hline $\begin{array}{l}\mathrm{P}\left(\mathrm{MEO}_{2} \mathrm{MA}_{93.9^{-}}\right. \\
\text {co-} \mathrm{MAAmBO}_{5.2^{-}} \\
\text {co-PyMA } \mathrm{MA.9}_{0.9}\end{array}$ & 93.9 & 5.3 & - & - & 0.9 & 2600 & 1.59 & 15.2 & no $\operatorname{LCST}^{\mathrm{f}}$ \\
\hline $\begin{array}{c}\mathrm{P}\left(\mathrm{MEO}_{2} \mathrm{MA}_{99.0^{-}}\right. \\
\left.c o-\mathrm{PyMA}_{1.0}\right)\end{array}$ & 99.0 & - & - & - & 1.0 & 12,500 & 1.31 & $21.3(1$ & PBS) \\
\hline
\end{tabular}

\subsection{Preparation of EVOH/BOP Nanofiber Meshes by Electro-Spinning}

BOPs can interact with $\mathrm{OH}$ groups in the EVOH. Kikuchi et al. reported a hydrogel that was composed of a boronic acid-based copolymer and a water-soluble poly(vinyl alcohol) (PVA) [39]. We have prepared hydro(nano)gels consisting of glyco-based copolymers and temperature-responsive $\mathrm{P}(\mathrm{N}$-isopropylacrylamide (NIPAAm)-co-MAAmBO)s [23,24]. The water-soluble glyco-based copolymers were mixed with $\mathrm{P}(\mathrm{NIPAAm}-\mathrm{co}-\mathrm{MAAmBO})$ in aqueous solution. However, EVOH 
is a water-insoluble copolymer, which means a good solvent for both copolymers has to be selected for the electro-spinning method. HFIP was selected as a good solvent. The EVOH

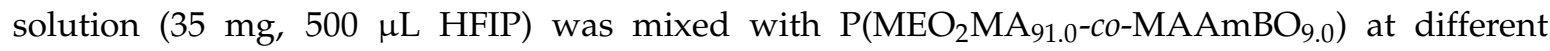
concentrations, and the mixed solutions were used in electro-spinning (Figure 3). At a low concentration of $\mathrm{P}\left(\mathrm{MEO}_{2} \mathrm{MA}_{91.0}-\mathrm{co}-\mathrm{MAAmBO}_{9.0}\right)(5 \mathrm{mg}, 500 \mu \mathrm{L}$ HFIP), nanofibers and aggregated particles were observed (Figure $3 \mathrm{~A}$ ). It has been observed that electro-spinning with a low viscous solution can result in aggregated particles [8]. When the concentration was increased using $\mathrm{P}\left(\mathrm{MEO}_{2} \mathrm{MA}_{91.0}-\mathrm{co}-\mathrm{MAAmBO}_{9.0}\right)(10 \mathrm{mg}$, $500 \mu \mathrm{L} \mathrm{HFIP})$, fine nanofiber formation was observed (Figure 3B). The interaction between $\mathrm{MAAmBO}$ and $\mathrm{OH}$ units led to the increase of the viscosity, resulting in the increasing superficial molecular weight. At high concentrations of $\mathrm{P}\left(\mathrm{MEO}_{2} \mathrm{MA}_{91.0}\right.$-co-MAAmBO $\left.{ }_{9.0}\right)(25 \mathrm{mg}, 500 \mu \mathrm{L}$ HFIP), gel formation was observed, which could not be from electro-spinning (Figure $3 \mathrm{C}$ ). Fine nanofibers were also obtained from other BOPs. Figure $4 \mathrm{~A}, \mathrm{~B}$ shows the nanofiber structures of $\mathrm{EVOH} / \mathrm{P}\left(\mathrm{MEO}_{2} \mathrm{MA}_{56.5}-\mathrm{co}-\mathrm{OEGMA}_{38.2}-\mathrm{co}-\mathrm{MAAmBO}_{5.3}\right)$ ( $25 \mathrm{mg}, 500 \mu \mathrm{L}$ HFIP) and EVOH/P(MEO $\left.\mathrm{MA}_{86.7}-\mathrm{co}-\mathrm{MAAmBO}_{4.8}-\mathrm{co}-\mathrm{Ac} 8.5\right)(10 \mathrm{mg}, 500 \mu \mathrm{L}$ HFIP), respectively. High MAAmBO content led to the need for a small amount of copolymers for the nanofiber structure. These results suggested that the nanofiber structures were affected by the MAAmBO contents, polymer concentrations and their mixture ratios. For example, imperfect nanofiber formation (with particle aggregation) was observed in the mixture of $\mathrm{P}\left(\mathrm{MEO}_{2} \mathrm{MA}_{69.7}-\mathrm{co}-\mathrm{OEGMA}_{30.3}\right)$ (25 mg) $\left(M_{\mathrm{n}}=25,400 \mathrm{~g} / \mathrm{mol}, M_{\mathrm{w}} / M_{\mathrm{n}}=1.28\right.$ [39]) (Figure 4C). The $\mathrm{P}\left(\mathrm{MEO}_{2} \mathrm{MA}_{69.7}\right.$-co-OEGMA 30.3$)$ has no MAAmBO unit and cannot interact with $\mathrm{EVOH}$. The lack of increase in viscosity led the imperfect nanofiber formation.
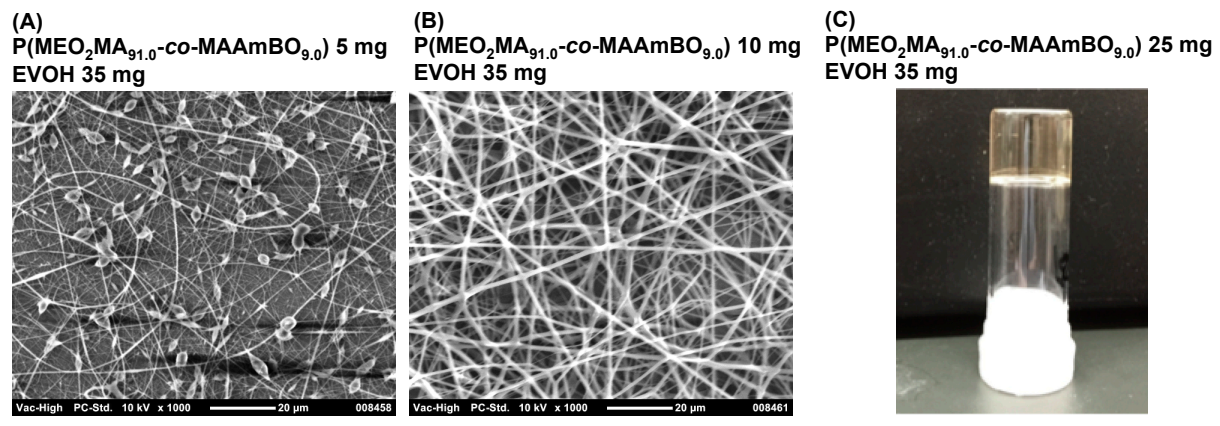

Figure 3. SEM image of electro-spinning samples of EVOH $(35 \mathrm{mg})$ and

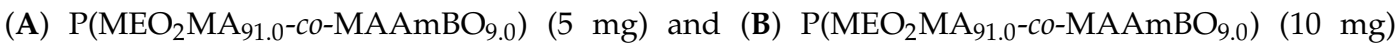
in $1 \mathrm{~mL}$ 1,1,1,3,3,3-hexafluoroisopropanol (HFIP). (C) Gel formation of EVOH (35 $\mathrm{mg}$ ) and $\mathrm{P}\left(\mathrm{MEO}_{2} \mathrm{MA}_{91.0}\right.$-co-MAAmBO 9.0$)(25 \mathrm{mg})$ in $1 \mathrm{~mL}$ HFIP.

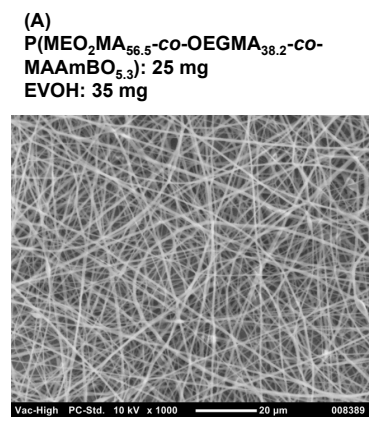

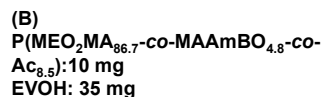
$\left.\mathrm{Ac}_{8.5}\right): 10 \mathrm{mg}$
EVOH: $35 \mathrm{mg}$

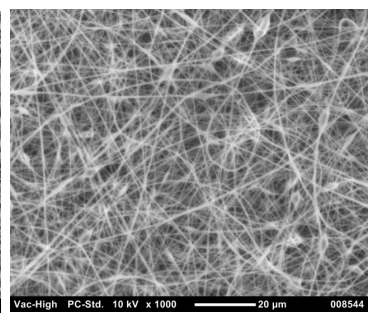

(C) 作 EVOH: $35 \mathrm{mg}$

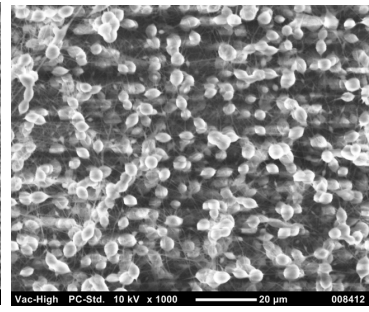

Figure 4. SEM images of electro-spinning samples: (A) $\mathrm{P}\left(\mathrm{MEO}_{2} \mathrm{MA}_{56.5}-c 0-\mathrm{OEGMA}_{38.2}-c o-\mathrm{MAAmBO}_{5.3}\right)$ (25 mg) and EVOH (35 mg); (B) $\mathrm{P}\left(\mathrm{MEO}_{2} \mathrm{MA}_{86.7}-\mathrm{co}-\mathrm{MAAmBO}_{4.8}-\mathrm{co}-\mathrm{Ac}_{8.5}\right)(10 \mathrm{mg})$ and EVOH (35 mg) and $(\mathbf{C}) \mathrm{P}\left(\mathrm{MEO}_{2} \mathrm{MA}_{69.7}-\mathrm{Co}-\mathrm{OEGMA}{ }_{30.3}\right)(25 \mathrm{mg})$ and EVOH $(35 \mathrm{mg})$ in $1 \mathrm{~mL}$ HFIP. 


\subsection{Stability Test of EVOH/BOP Nanofiber Meshes}

Multi-step organic reactions are needed to modify molecules in EVOH materials. By simple mixing, the EVOH nanofiber mesh was easily modified with the BOPs. As the copolymers, $\mathrm{P}\left(\mathrm{MEO}_{2} \mathrm{MA}_{93.9}-\mathrm{co}-\mathrm{MAAmBO}_{5.2}-c 0-\mathrm{PyMA}_{0.9}\right)$ and $\mathrm{P}\left(\mathrm{MEO}_{2} \mathrm{MA}_{99.0}-c o-\mathrm{PyMA}_{1.0}\right)$ were selected (Table 1 and Figure 2). The fluorescent molecule of PyMA can trace the morphology change of a polymer, chain and the fluorescent intensity can also be an indicator for cell biology [40]. To prevent the LCST change via the hydrophobic PyMA units, the PyMA contents in the copolymers were adjusted less

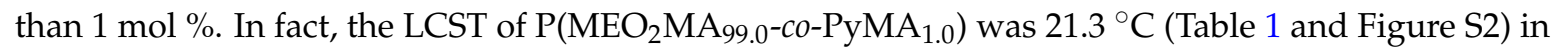
$\mathrm{pH}$ 7.4 PBS, which was similar to that of the $\mathrm{P}\left(\mathrm{MEO}_{2} \mathrm{MA}\right)$ homopolymer (LCST: $23^{\circ} \mathrm{C}$ in PBS [40]). The stability of the nanofiber meshes of $\mathrm{EVOH} / \mathrm{BOP}$ was measured at various solution conditions. $\mathrm{EVOH} / \mathrm{P}\left(\mathrm{MEO}_{2} \mathrm{MA}_{93.9}-\mathrm{co}-\mathrm{MAAmBO}_{5.2}-\mathrm{co}-\mathrm{PyMA}_{0.9}\right)$ nanofiber meshes were immersed for $24 \mathrm{~h}$ in $\mathrm{pH}$ $2\left(\mathrm{HCl}_{\mathrm{aq}}\right)$ and $12\left(\mathrm{NaOH}_{\mathrm{aq}}\right)$ at different solution temperatures $\left(4\right.$ and $\left.37^{\circ} \mathrm{C}\right)$. Figure $5 \mathrm{~A}$ shows the SEM images of $\mathrm{EVOH} / \mathrm{P}\left(\mathrm{MEO}_{2} \mathrm{MA}_{93.9}-\mathrm{co}-\mathrm{MAAmBO}_{5.2}-\mathrm{co}-\mathrm{PyMA}_{0.9}\right)$ nanofiber meshes. After immersion treatment, there was no outward morphology change on the nanofiber structure (Figure S3A,B). At the same immersion conditions, particle aggregation was observed in the modified EVOH nanofiber with $\mathrm{P}\left(\mathrm{MEO}_{2} \mathrm{MA}_{99.0}\right.$-co-PyMA $\left.{ }_{1.0}\right)$ (Figure 5B and Figure S3C-F). The weight loss of the nanofiber meshes after immersion is shown in Figure 5C. In the $\mathrm{P}\left(\mathrm{MEO}_{2} \mathrm{MA}_{93.9}-c o-\mathrm{MAAmBO}_{5.2}-\mathrm{co}-\mathrm{PyMA}_{0.9}\right)$ at $\mathrm{pH} 12$, the weight losses were small at both 4 and $37^{\circ} \mathrm{C}$; over $97 \%$ of copolymers remained in the nanofiber structure. The high stability is a result of the interaction between $\mathrm{EVOH}$ and MAAmBO units. Interestingly, at $\mathrm{pH} 2$, the weight losses were also small at both 4 and $37^{\circ} \mathrm{C}$ (over $98 \%$ of copolymer remained in the nanofiber). The small weight loss might be due to three reasons: (1) polymeric entanglement; (2) hydrophobic-hydrophobic interaction; and (3) boroxole and cis-diol interaction at acidic condition [35,36]. On the other hand, the weight losses of $\mathrm{P}\left(\mathrm{MEO}_{2} \mathrm{MA}_{99.0}\right.$-co-PyMA $\left.\mathrm{P}_{1.0}\right)$ that cannot interact with $\mathrm{EVOH}$ via the covalent bonding were 86.6 and $86.7 \%$ at 4 and $37{ }^{\circ} \mathrm{C}$, respectively. Moreover, after the immersion test, the supernatant liquid was also measured using a fluorescent detector to estimate the released amount of the $\mathrm{P}\left(\mathrm{MEO}_{2} \mathrm{MA}_{99.0}-\mathrm{co}-\mathrm{PyMA}_{1.0}\right)$ from the nanofiber meshes. The standard straight line (fluorescent intensity vs. concentration) was made from $\mathrm{P}\left(\mathrm{MEO}_{2} \mathrm{MA}_{99.0}\right.$-co-PyMA $\left.{ }_{1.0}\right)\left(R^{2}=0.991\right)$. The calculated release of $\mathrm{P}\left(\mathrm{MEO}_{2} \mathrm{MA}_{99.0}\right.$-co-PyMA $\left.\mathrm{P}_{1.0}\right)$ was $5 \%$ at $4{ }^{\circ} \mathrm{C}$. There was a difference in the calculated release between the weight loss measurements and the concentration determined by fluorescent intensity. The supernatant liquid might have a very small amount of $\mathrm{EVOH}$, which led to a different external environment as compared to that of free $\mathrm{P}\left(\mathrm{MEO}_{2} \mathrm{MA}_{99.0}-\mathrm{co}-\mathrm{PyMA}_{1.0}\right)$, resulting in the discrepancy with the standard straight line.
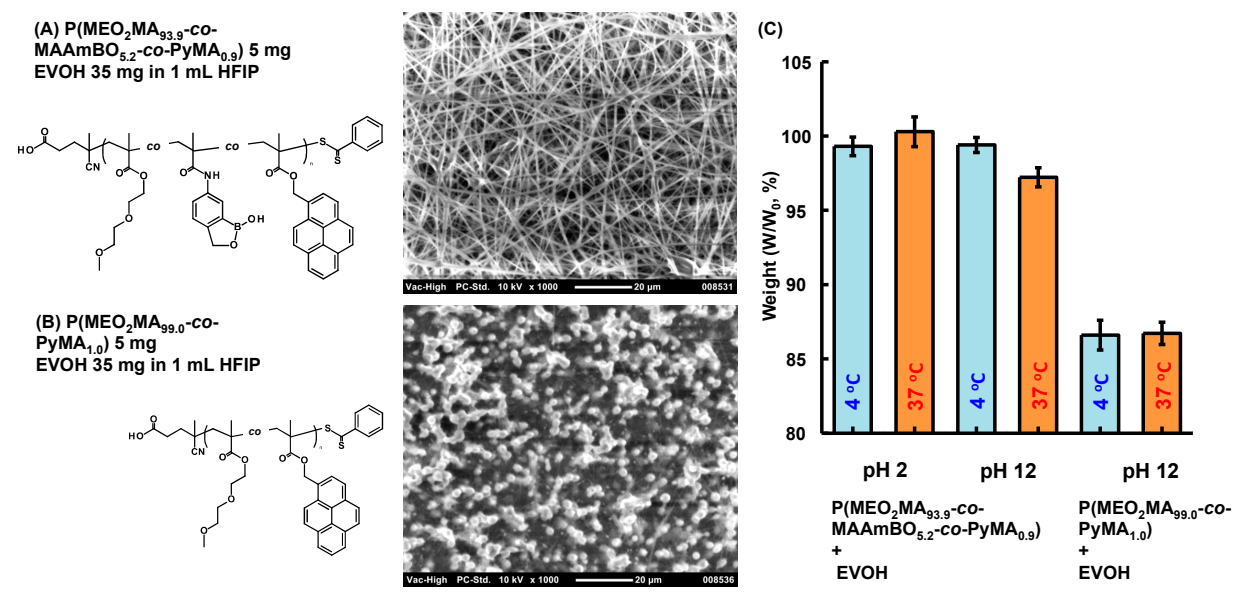

Figure 5. SEM images of electro-spinning samples: (A) $\mathrm{P}\left(\mathrm{MEO}_{2} \mathrm{MA}_{93.9}-c o-\mathrm{MAAmBO}_{5.2}-c o-\mathrm{PyMA}_{0.9}\right)$

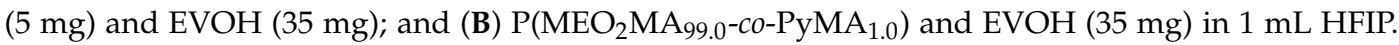
(C) Weight loss ((weight after immersion test, $W) /\left(\right.$ weight before immersion test, $\left.W_{0}\right) \times 100 \%$ ) at various immersion conditions for $24 \mathrm{~h}$. 


\subsection{Controlled Adsorption and Desorption of Cationic Dye on Anionic EVOH/Benzoxaborole} Nanofiber Meshes

The nanofiber of $\mathrm{EVOH} / \mathrm{P}\left(\mathrm{MEO}_{2} \mathrm{MA}_{86.7}-\mathrm{co}-\mathrm{MAAmBO}_{4.8}-\mathrm{co}-\mathrm{Ac}_{8.5}\right)$ was utilized for its $\mathrm{pH}$-responsive property in a molecule catch and release system. The $\mathrm{pH}$-responsive units of the $\mathrm{P}\left(\mathrm{MEO}_{2} \mathrm{MA}_{86.7}-\mathrm{co}-\mathrm{MAAmBO}_{4.8}-\mathrm{co}-\mathrm{Ac}_{8.5}\right)$ occur due to the carboxylic acid located in the Ac unit. At $\mathrm{pH} \mathrm{2,} \mathrm{the} \mathrm{LCST} \mathrm{was} 17.6{ }^{\circ} \mathrm{C}$. On the other hand, at $\mathrm{pH} 12$, no transmittance change was observed due to the electrostatic repulsion of both MAAmBO and Ac units (Table 1). Therefore, the surface properties of functionalized $\mathrm{EVOH}$ nanofiber mesh will be altered at different $\mathrm{pH}$ via the mixed $\mathrm{P}\left(\mathrm{MEO}_{2} \mathrm{MA}_{86.7}-\mathrm{co}-\mathrm{MAAmBO}_{4.8}-\mathrm{co}-\mathrm{Ac}_{8.5}\right)$. The anionic $\mathrm{EVOH} / \mathrm{P}\left(\mathrm{MEO}_{2} \mathrm{MA}_{86.7}-\mathrm{co}-\mathrm{MAAmBO}_{4.8}-\mathrm{co}-\mathrm{Ac}_{8.5}\right)$ nanofiber mesh was immersed in cationic methylene blue solution at pH 7.4 PBS (Figure 6). The anionic charged nanofiber mesh was expected to adsorb the methylene blue strongly via an electrostatic interaction as compared to that of only $\mathrm{EVOH}$ nanofiber mesh. In fact, the $\mathrm{EVOH} / \mathrm{P}\left(\mathrm{MEO}_{2} \mathrm{MA}_{86.7}-\mathrm{co}-\mathrm{MAAmBO}_{4.8}-\mathrm{co}-\mathrm{A} \mathrm{c}_{8.5}\right)$ nanofiber mesh strongly adsorbed the blue dye more than that of the EVOH nanofiber mesh. The dyed nanofiber meshes were immersed in $\mathrm{pH} 2$ solution to release the methylene blue via the $\mathrm{pH}$-responsive property of the Ac units in the $\mathrm{P}\left(\mathrm{MEO}_{2} \mathrm{MA}_{86.7}-\mathrm{co}-\mathrm{MAAmBO}_{4.8}-\mathrm{co}-\mathrm{Ac} 8.5\right)$. After $15 \mathrm{~min}$, the blue color clearly turned light. In other words, the functionalized $\mathrm{EVOH}$ nanofiber mesh achieved a controlled molecule adsorption and desorption depending on the solution $\mathrm{pH}$. The nanofibers were reusable for the controlled adsorption/desorption of methylene blue (Figure S4). These results suggested that the $\mathrm{pH}$-responsive properties of BOPs were imparted into the electro-spun EVOH nanofiber meshes. This simple functionalization system will be a useful tool in expanding the application field of EVOH (nano)materials.

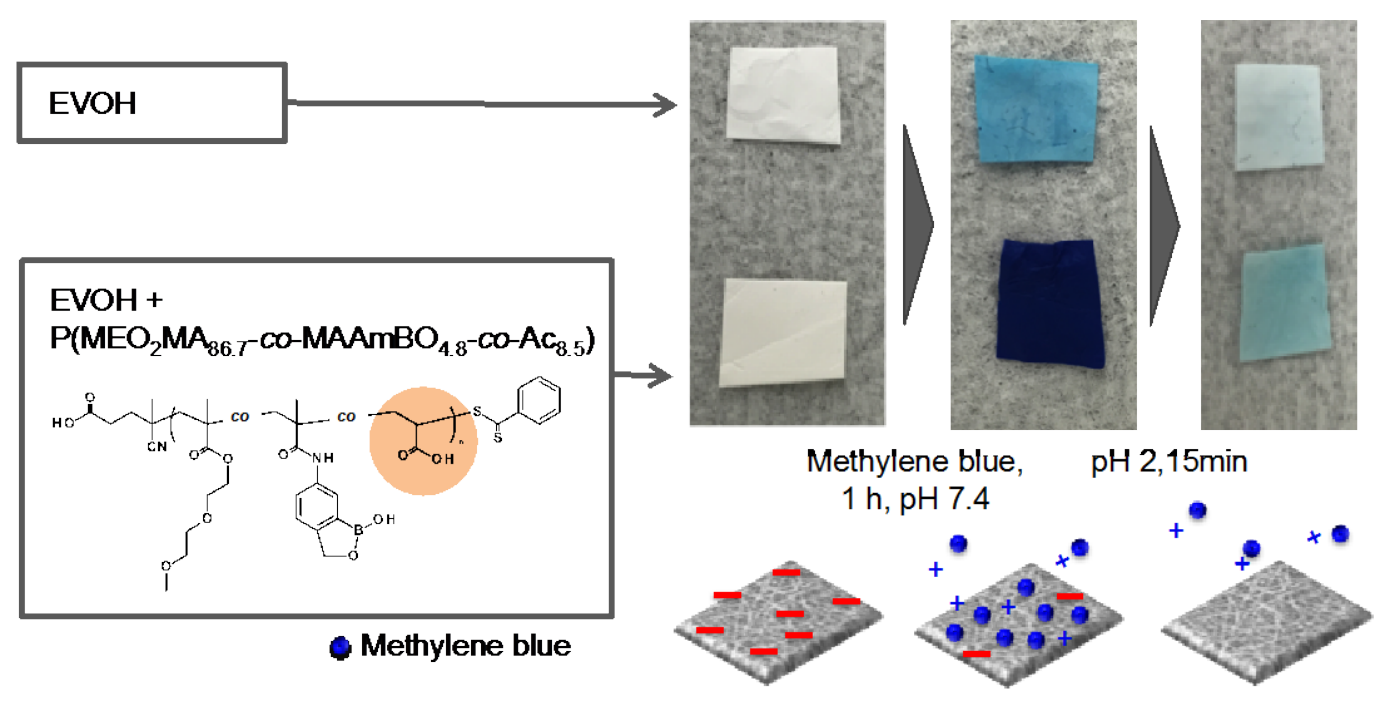

Figure 6. $\mathrm{pH}$-responsive dye tests of the $\mathrm{EVOH}$ nanofiber and $\mathrm{EVOH} / \mathrm{P}\left(\mathrm{MEO}_{2} \mathrm{MA}_{86.7}-\mathrm{co}-\mathrm{MAAmBO}_{4.8}-\mathrm{co}-\mathrm{Ac}_{8.5}\right)$ nanofiber using methylene blue solution. Blue and red colors in the illustration are cationic methylene blue and anionic Ac units, respectively.

\section{Conclusions}

In conclusion, we proposed a facile functionalization method of $\mathrm{EVOH}$ nanofiber meshes using the BOPs via their reversible benzoxaborole-diol interaction. The mixture solution of EVOH and BOPs was prepared in HFIP for electro-spinning; it was found that the benzoxaborole-diol interaction occurred in the organic solvent. The interaction resulted in increased viscosity, which supported the fabrication of a fine nanofiber structure. The structure of the nanofiber mesh was strongly affected by the benzoxaborole content, polymer concentration and the mixture ratios. Particles and bulk gels were also formed depending on the preparation conditions. The modified EVOH nanofiber meshes showed 
a high stability in acid or alkali aqueous solutions. After a 24-h immersion test, over 97\% of EVOH and BOP remained within the nanofiber mesh. According to the SEM images, there was no morphology change in the nanofiber structure after the immersion test. Moreover, the EVOH nanofiber mesh was also functionalized with BOP having $\mathrm{pH}$-responsive $\mathrm{COOH}$ groups. The anionic charged nanofiber mesh was strongly dyed by methylene blue due to the electrostatic interaction as compared to that of the EVOH nanofiber mesh in $\mathrm{pH}$ 7.4. The dye was rapidly released from the fiber mesh in acidic condition. This simple and effective functionalization system for EVOH (nano)materials could lead to an expansion of their applications into new fields.

Supplementary Materials: Supplementary materials can be found at www.mdpi.com/2073-4360/8/2/41/s1.

Acknowledgments: This study was partially supported by research funds from the International Center for Young Scientists (ICYS), National Institute for Materials Science (NIMS), Japan.

Author Contributions: Yohei Kotsuchibashi conceived of and conducted the experiments. This paper was written by Yohei Kotsuchibashi and Mitsuhiro Ebara.

Conflicts of Interest: The authors declare no conflict of interest.

\section{References}

1. Mokwena, K.K.; Tang, J. Ethylene vinyl alcohol: A review of barrier properties for packaging shelf stable foods. Crit. Rev. Food Sci. Nutr. 2012, 52, 640-650. [CrossRef] [PubMed]

2. Itoh, S.; Suzuki, C.; Tsuji, T. Platelet activation through interaction with hemodialysis membranes induces neutrophils to produce reactive oxygen species. J. Biomed. Mater. Res. A 2006, 77, 294-303. [CrossRef] [PubMed]

3. Sirolli, V.; Ballone, E.; Stante, S.D.; Amoroso, L.; Bonomini, M. Cell activation and cellular-cellular interactions during hemodialysis: Effect of dialyzer membrane. Int. J. Artif. Organs 2002, 25, 529-537. [PubMed]

4. Shang, M.; Matsuyama, H.; Teramoto, M.; Lloyd, D.R.; Kubota, N. Preparation and membrane performance of poly(ethylene-co-vinylalcohol) hollow fiber membrane via thermally induced phase separation. Polymer 2003, 44, 7441-7447.

5. Lee, M.-H.; Thomas, J.L.; Ho, M.-H.; Yuan, C.; Lin, H.-Y. Synthesis of magnetic molecularly imprinted poly(ethylene-co-vinyl alcohol) nanoparticles and their uses in the extraction and sensing of target molecules in urine. ACS Appl. Mater. Interfaces 2010, 2, 1729-1736. [PubMed]

6. Lv, R.; Zhou, J.; Du, Q.; Wang, H.; Zhong, W. Effect of posttreatment on morphology and properties of poly(ethylene-co-vinyl alcohol) microporous hollow fiber via thermally induced phase separation. J. Appl. Polym. Sci. 2007, 104, 4106-4112.

7. Kenawy, E.-R.; Layman, J.M.; Watkins, J.R.; Bowlin, G.L.; Matthews, J.A.; Simpson, D.G.; Wnek, G.E. Electrospinning of poly(ethylene-co-vinyl alcohol) fibers. Biomaterials 2003, 24, 907-913.

8. Namekawa, K.; Tokoro, M.S.; Aoyagi, T.; Ebara, M. Fabrication of zeolite-polymer composite nanofibers for removal of uremic toxins from kidney failure patients. Biomater. Sci. 2014, 2, 674-679.

9. Zhou, J.; Meng, S.; Guo, Z.; Du, Q.; Zhong, W. Phosphorylcholine-modified poly(ethylene-co-vinyl alcohol) microporous membranes with improved protein-adsorption-resistance property. J. Membrane Sci. 2007, 305, 279-286.

10. Zhu, J.; Sun, G. Facile fabrication of hydrophilic nanofibrous membranes with an immobilized metal-chelate affinity complex for selective protein separation. ACS Appl. Mater. Interfaces 2014, 6, 925-932. [PubMed]

11. Hong, S.I.; Kim, K.B.; Lee, Y.; Cho, S.Y.; Ko, J.A.; Hong, S.K.; Park, H.J. Surface modification of ethylene-vinyl alcohol copolymer treated with plasma source ion implantation. J. Appl. Polym. Sci. 2009, 113, 2988-2996.

12. Buntinx, M.; Willems, G.; Knockaert, G.; Adons, D.; Yperman, J.; Carleer, R.; Peeters, R. Evaluation of the thickness and oxygen transmission rate before and after thermoforming mono- and multi-layer sheets into trays with variable depth. Polymers 2014, 6, 3019-3043.

13. Son, T.W.; Lim, S.K.; Lee, D.W.; Lee, E.W. Physical modification of polypropylene. III. Novel morphology of polypropylene and poly(ethylene-co-vinyl alcohol) with epoxy blend fibers. J. Appl. Polym. Sci. 1999, 73, 1049-1057. 
14. Neppalli, R.; Causin, V.; Marigo, A.; Meincken, M.; Hartmann, P.; Reenen, A.J. Effect of electrospun ethylene vinyl alcohol copolymer $(\mathrm{EVOH})$ fibres on the structure, morphology, and properties of poly(lactic acid) (PLA). Polymer 2013, 54, 5909-5919. [CrossRef]

15. Martínez-Sanz, M.; Olsson, R.T.; Lopez-Rubio, A.; Lagaron, J.M. Development of bacterial cellulose nanowhiskers reinforced EVOH composites by electrospinning. J. Appl. Polym. Sci. 2012, 124, 1398-1408. [CrossRef]

16. Shimada, N.; Tsutsumi, H.; Nakane, K.; Ogihara, T.; Ogata, N. Poly(ethylene-co-vinyl alcohol) and nylon 6/12 nanofibers produced by melt electrospinning system equipped with a line-like laser beam melting device. J. Appl. Polym. Sci. 2010, 116, 2998-3004. [CrossRef]

17. Wang, D.; Xu, W.; Sun, G.; Chiou, B. Radical graft polymerization of an allyl monomer onto hydrophilic polymers and their antibacterial nanofibrous membranes. ACS Appl. Mater. Interfaces 2011, 3, 2838-2844. [CrossRef] [PubMed]

18. Xu, D.; Zhu, K.; Zheng, X.; Xiao, R. Poly(ethylene-co-vinyl alcohol) functional nanofiber membranes for the removal of Cr(VI) from water. Ind. Eng. Chem. Res. 2015, 54, 6836-6844. [CrossRef]

19. Kouzu, T.; Hirata, Y.; Hamada, K. Sorption of water vapor of EVAL/PAA blend nano-nonwovens modified by layer-by-layer technique. Desalin. Water Treat. 2010, 17, 2-9.

20. Benaglia, M.; Chiefari, J.; Chong, Y.K.; Moad, G.; Rizzardo, E.; Thang, S.H. Universal (switchable) RAFT agents. J. Am. Chem. Soc. 2009, 131, 6914-6915. [CrossRef] [PubMed]

21. Rowan, S.J.; Cantrill, S.J.; Cousins, G.R.L.; Sanders, J.K.M.; Stoddart, J.F. Dynamic covalent chemistry. Angew. Chem. Int. Ed. 2002, 41, 898-952.

22. Otsuka, H. Reorganization of polymer structures based on dynamic covalent chemistry: Polymer reactions by dynamic covalent exchanges of alkoxyamine units. Polym. J. 2013, 45, 879-891.

23. Kotsuchibashi, Y.; Agustin, R.V.C.; Lu, J.-Y.; Hall, D.G.; Narain, R. Temperature, pH, and glucose responsive gels via simple mixing of boroxole- and glyco-based polymers. ACS Macro. Lett. 2013, 2, 260-264.

24. Kotsuchibashi, Y.; Ebara, M.; Sato, T.; Wang, Y.; Rajender, R.; Hall, D.G.; Narain, R.; Aoyagi, T. Spatiotemporal control of synergistic gel disintegration consisting of boroxole- and glyco-based polymers via photoinduced proton transfer. J. Phys. Chem. B 2015, 119, 2323-2329. [PubMed]

25. Techawanitchai, P.; Ebara, M.; Idota, N.; Aoyagi, T. Light-induced spatial control of pH-jump reaction at smart gel interface. Colloids Surf. B 2012, 99, 53-59. [CrossRef] [PubMed]

26. Pal, A.; Bérubé, M.; Hall, D.G. Design, synthesis, and screening of a library of peptidyl bis(boroxoles) as oligosaccharide receptors in water: Identification of a receptor for the tumor marker TFantigen disaccharide. Angew. Chem. Int. Ed. 2010, 49, 1492-1495.

27. Ellis, G.A.; Palte, M.J.; Raines, R.T. Boronate-mediated biologic delivery. J. Am. Chem. Soc. 2012, 134, 3631-3634. [CrossRef] [PubMed]

28. Mahalingam, A.; Geonnotti, A.R.; Balzarini, J.; Kiser, P.F. Activity and safety of synthetic lectins based on benzoboroxole-functionalized polymers for inhibition of HIV entry. Mol. Pharm. 2011, 8, 2465-2475. [CrossRef] [PubMed]

29. Qiao, Z.; Wang, Q.; Zhang, F.; Wang, Z.; Bowling, T.; Nare, B.; Jacobs, R.T.; Zhang, J.; Ding, D.; Liu, Y.; et al. Chalcone-benzoxaborole hybrid molecules as potent antitrypanosomal agents. J. Med. Chem. 2012, 55, 3553-3557. [CrossRef] [PubMed]

30. Jay, J.I.; Lai, B.E.; Myszka, D.G.; Mahalingam, A.; Langheinrich, K.; Katz, D.F.; Kiser, P.F. Multivalent benzoboroxole functionalized polymers as gp120 glycan targeted microbicide entry inhibitors. Mol. Pharm. 2010, 7, 116-129. [CrossRef] [PubMed]

31. Böeseken, J. The use of boric acid for the determination of the configuration of carbohydrates. Adv. Carbohydr. Chem. 1949, 4, 189-210.

32. Matsumoto, A.; Yamamoto, K.; Yoshida, R.; Kataoka, K.; Aoyagi, T.; Miyahara, Y. A totally synthetic glucose responsive gel operating in physiological aqueous conditions. Chem. Commun. 2010, 46, 2203-2205. [CrossRef] [PubMed]

33. Qin, Y.; Cheng, G.; Sundararaman, A.; Jäkle, F. Well-defined boron-containing polymeric lewis acids. J. Am. Chem. Soc. 2002, 124, 12672-12673. [CrossRef] [PubMed]

34. Dowlut, M.; Hall, D.G. An improved class of sugar-binding boronic acids, soluble and capable of complexing glycosides in neutral water. J. Am. Chem. Soc. 2006, 128, 4226-422. [CrossRef] [PubMed] 
35. Liu, C.T.; Tomsho, J.W.; Benkovic, S.J. The unique chemistry of benzoxaboroles: Current and emerging applications in biotechnology and therapeutic treatments. Bioorg. Med. Chem. 2014, 22, 4462-4473. [CrossRef] [PubMed]

36. Adamczyk-Woźniak, A.; Borys, K.M.; Sporzyński, A. Recent developments in the chemistry and biological applications of benzoxaboroles. Chem. Rev. 2015, 115, 5224-5247. [CrossRef] [PubMed]

37. Lutz, J.-F.; Akdemir, Ö.; Hoth, A. Point by point comparison of two thermosensitive polymers exhibiting a similar LCST: Is the age of Poly(NIPAM) over? J. Am. Chem. Soc. 2006, 128, 13046-13047. [CrossRef] [PubMed]

38. Wang, Y.; Kotsuchibashi, Y.; Uto, K.; Ebara, M.; Aoyagi, T.; Liu, Y.; Narain, R. pH and glucose responsive nanofibers for the reversible capture and release of lectins. Biomater. Sci. 2015, 3, 152-162. [CrossRef]

39. Kikuchi, A.; Suzuki, K.; Okabayashi, O.; Hoshino, H.; Kataoka, K.; Sakurai, Y.; Okano, T. Glucose-sensing electrode coated with polymer complex gel containing phenylboronic acid. Anal. Chem. 1996, 68, 823-828.

40. Kotsuchibashi, Y.; Ebara, M.; Hoffman, A.S.; Narain, R.; Aoyagi, T. Temperature-responsive mixed core nanoparticle properties determined by the composition of statistical and block copolymers in the core. Polym. Chem. 2015, 6, 1693-1697.

(C) 2016 by the authors; licensee MDPI, Basel, Switzerland. This article is an open access article distributed under the terms and conditions of the Creative Commons by Attribution (CC-BY) license (http://creativecommons.org/licenses/by/4.0/). 